\title{
What's in a name? \\ James Burbage and his Playhouse
}

\author{
C. W. R. D. Moseley
}

When the joiner James Burbage, borrowing 1000 marks from his brother in law John Brayne the grocer, built a new playhouse in Shoreditch in 1576, why did they decide to call it "The Theatre" (note, by the way, the definite article)? When the Burbages, desperate to generate some income, were nearly bankrupt after the debacle when the NIMBYs stopped them using the expensively-converted frater at Blackfriars, they rebuilt the frame of The Theatre on the South Bank. Why did they then call it "The Globe"? Other theatre names hang over from inns - Red Bull, Rose, Hope, Swan, Belle Savage and, later, from former use, the Cockpit. Even in 1577 the next purpose-built theatre, 200 yards away, built (as was The Theatre) by the young carpenter Peter Street, was called the Curtain because it was near a plot of land called Curtain Close. "The Theatre" is clearly the odd one out, ${ }^{1}$ and it is difficult to think what sort of sign the place might have been given. ${ }^{2}$

What did that word "theatre" advertise, and what expectations did it arouse in 1576? As Lois Potter remarks, "the Greek-derived name would have been exotic". ${ }^{3}$ It is clearly so regarded by, for example, John Stockwood, in his contemptuous remark in a sermon on St Bartholomew's Day, 1578, about "The gorgeous Playing place erected in the fieldes... as they please to haue it called, a Theatre." One can hear the intonation. According to $O E D$, the word is first recorded in Chaucer's translation of Boethius. The 1382 Bible (Wycliffite E.V.) Acts xix. 29, describing the riot in the theatre in Ephesus, has to gloss the word - which clearly therefore was not in common use - as "comune biholdyng place" - not a bad translation of the Greek word, as it happens. Lydgate (Troy Book, iii. 5442) does suggest a connection with acting, "In compleynynge, pitously in rage, In pe theatre, with a ded visage," but in 1541 Thomas Elyot (Image of Gouernance, 1540, xxii. f. 42), "Many wolde resorte to the common houses callyd Theatres, and purposyng some matter of philosophye, wolde there dyspute openly." This suggests the word is still not a familiar English one. In 1591 Spenser in The Ruines of Time [in Complaints 92] links "goodly theaters" with "High towers, faire temples" - the public buildings at the heart of a city, as does Vitruvius: ${ }^{4}$ but he is referring to the ruins of Rome. There are very few examples in $O E D$ of the word's use much before, well, the building of The Theatre; then it becomes almost immediately much commoner both as proper name and, increasingly, in our sense (see information panel). There is, however, an intriguing use in 1581, in Conference about the next Succession (1584) ii. sig. K iv, "They are set before all mens eyes, and in the middest of the Theatre of the whole world" (my emphasis). 
For, by contrast, in Latin, the word is common, especially in the conceit of the Theatrum Mundi, whether or not in exactly those words. ${ }^{5}$ John of Salisbury has been credited (Policraticus, 1159) with first using the phrase (remarking that since all men are actors, there must be spectators to watch and judge them). ${ }^{6}$ But the metaphor can have two significances: first, it may divide a world of appearances, that of ordinary experience, from the true reality. Second, it can stress the essential hypocrisy and falseness of human behaviour rather than the possibility of clearer perception of true being. To put it perhaps too sharply, it can be either a showing and seeing place or a showing off and being seen place. And neither sense need preclude the other. In 1559 Calvin uses the word to describe the world, this "magnificent theatre of heaven and earth" as the manifestation to human sense of the spectacle of God's glory, almost as Augustine would have understood it. ${ }^{7}$ Yet in I Corinthians 4.9 St Paul says that Christians, "fools for Christ's sake," are performing a spectaculum before the whole universe. Thus the idea of theatrum is intimately connected with "seeing" - its Greek root sense as "knowing," but also with ideas of performance and pretence, and, of course, one person can do both, even at the same time. Thus the metaphor of the theatrum mundi, if taken seriously, both shows to the audience and challenges them as themselves performers. Its implications are thus inescapably moral and epistemological.

A trawl through the British Library cata-

\section{Early instances of "theatre" in $O E D$}

?1577 "Those places...whiche are made vppe and builded for suche Playes and Enterludes, as the Theatre and Curtaine is." J. Northbrooke, Spiritus est Vicarius Christi: Treat. Dicing (59).

1578 "If you resorte to the Theatre, the Curtayne, and other places of Playes in the Citie." J. Stockwood, Serm. Barthelmew Day (24).

1578 "The gorgeous Playing place erected in the fieldes...as they please to haue it called, a Theatre." J. Stockwood, Serm. Barthelmew Day (134).

1597 "As in a Theater the eies of men, After a well-graced Actor leaues the stage, Are ydly bent on him that enters next." William Shakespeare, Richard II (5.2.23)

1587 "It was found better for them by the aduise of the prince of Orange..to tarie for his highnesse vpon a theater which was prepared for him." A. Fleming et al. Holinshed's Chron. (new ed.) III. Contin. $1334 / 1$.

1581 "They...are set before all mens eyes, and in the middest of the Theatre of the whole world ..." in Confer. (1584) ii. sig. K iv.

1589 "A theater, or scaffold whereon musitions, singers, or such like shew their cunning, orchestra." J. Rider Bibliotheca Scholastica (1484). 
logues throws up a few books with the word in their title, mainly German or Dutch printings - I would not, mark you, underestimate the links with Holland or the Dutch language in late mediaeval and early modern London. There is a bit of a flurry in the 1560s and 70s of such books, mostly all moral, or moralising. From Basel in 1565 is Lycosthene's Theatrum uitæ humanæ ... à Conrado Lycosthene ... iampridem inchoatum: nunc uerò Theodori Zuinggeri ... opera, studio \& labore ... deductum (Bynneman), and Day printed a French version in London in 1568. A frequently re-issued offering is Pierre Boaistuau's Theatrum mundi the theatre or rule of the world, wherein may be sene

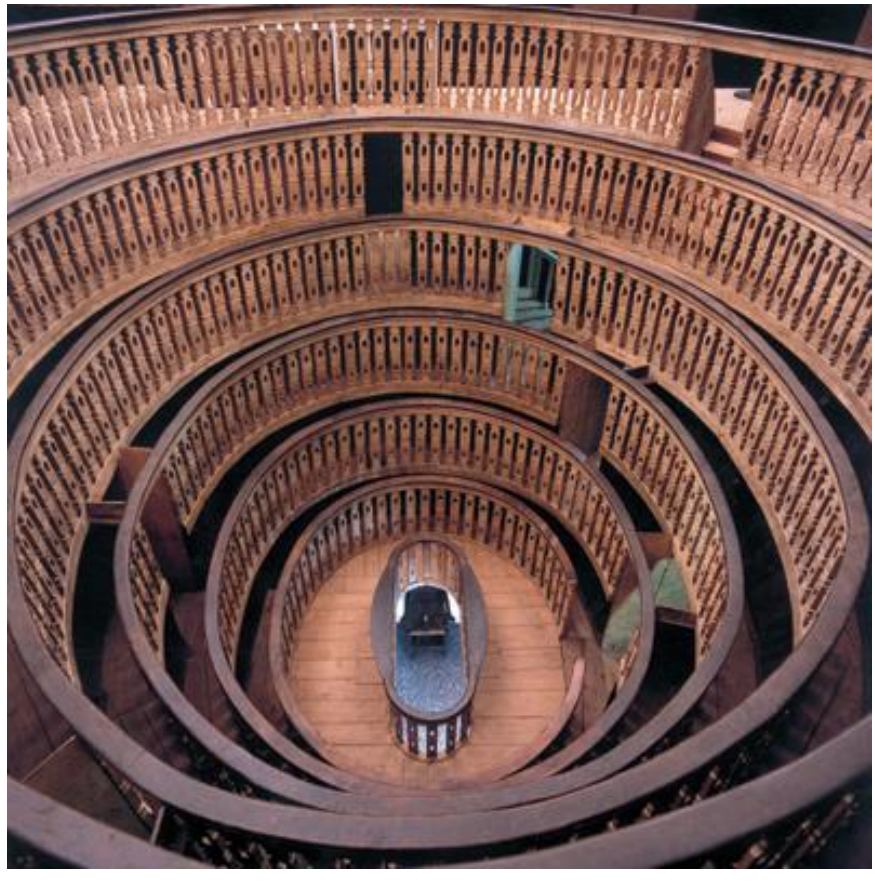

Figure 1 The Anatomy Theatre, Padua.
[NB] the running race and course of euerye mans life, as touching miserie and felicity, wherin be contained wonderfull examples, learned deuises, to the ouerthrowe of vice, and exalting of vertue. wherevnto is added a learned, and maruellous worke of the excellencie of mankinde. Written in the Frenche \& Latin tongues by Peter Boaystuau, and translated into English by Iohn Alday (1566; several editions in Latin and English). Jan van der Noot's Antwerp 1568 volume Het Theatre oft Too-neel, was Englished (partly by Spenser) in 1569 as A Theatre for Worldlings.

In France the word had already been associated in 1536 by Guillaume de La Perrière with the complex moral and didactic form of the emblem, a hybrid of words and picture: Le Theatre des Bons Engins, auquel sont contenuz cent Emblemes. (Lyons? 1536) and this work was translated in 1593 (second edition 1614) by Thomas Combe, who as it happens may well have come from Stratford, and it was certainly printed by a Stratford man, Richard Field, who printed a lot of the books we know Shakespeare used as well as his own Venus and Adonis and Lucrece. Emblems are not simply a quaint small form of negligible importance: in their time, in their complex allusiveness and ambiguity of relationship between words and picture, they were aggressively topical, analytical and coded utterances. Moreover, visual symbol was the usual Renaissance way of conceptualizing abstraction, and this I do not think irrelevant to how drama was experienced. But: the point is that these titles almost without exception signal a moral purpose.

Where else might the more learned of the building's first customers have encountered it? With the exception of Ortelius' atlas, Theatrum 


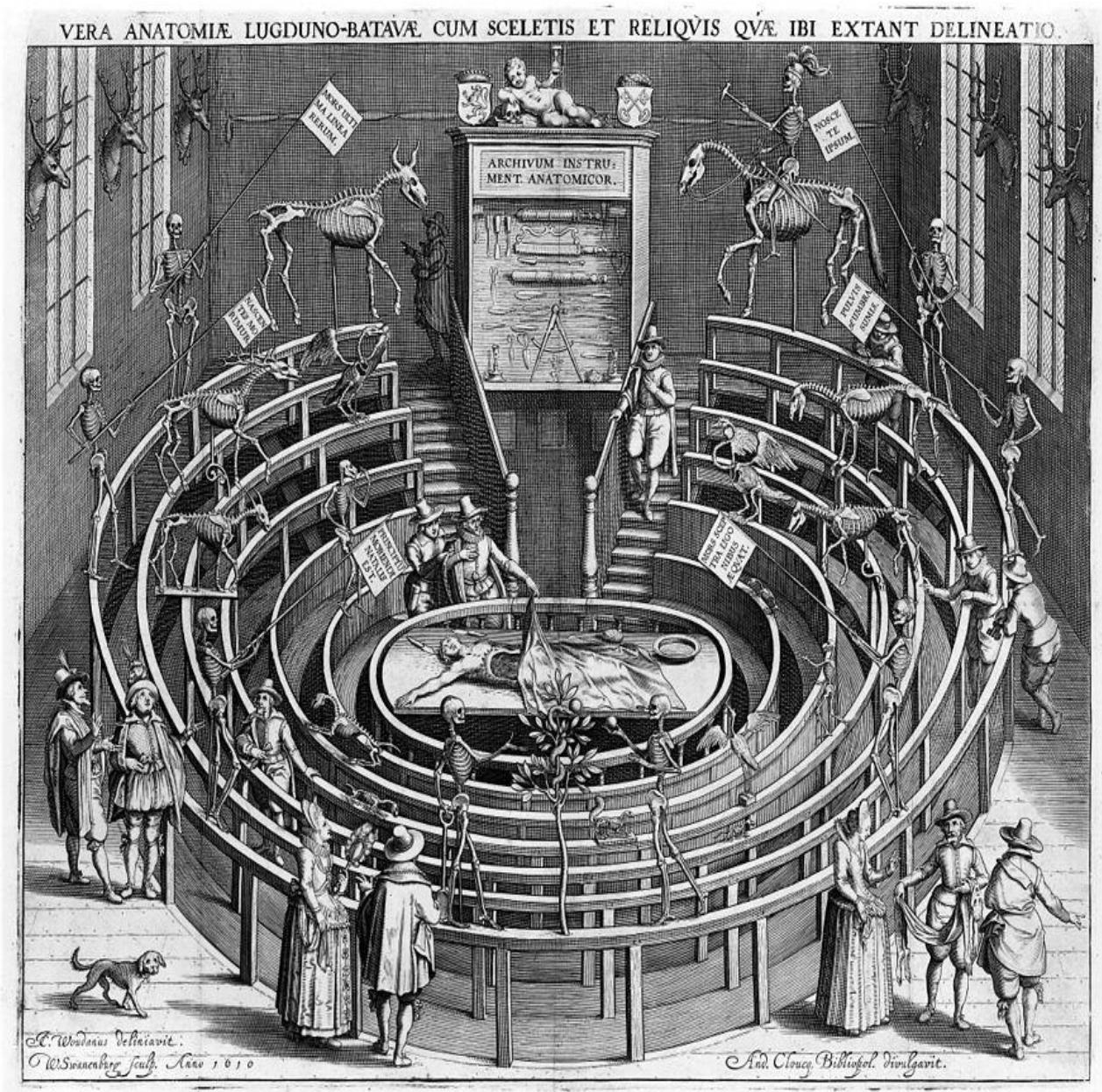

Figure 2 The anatomy theatre at Leiden. Wikimedia Commons.

Orbis Terrarum, $(1570,1573)$, the other uses of the word in titles are mainly in medical books and very soon, medical education. For example: Theatrum Galeni, hoc est, universæ medicinæ a ... Galeno diffuse sparsimque traditæ Promptuarium quo vel indicis loco in omnes Galeni libros [of the Basle edition, 1562], vel locorum communium instar in re medica: lector ... utetur. A. Mundellæ ... studio \& labore ... conditum, \& nunc demum editum. And it is precisely at this time that anatomy theatres, seeing or demonstration places, as the Greek $\Theta \eta \alpha ́ \tau \rho o v ~ s u g g e s t s$, begin to be built. The permanent anatomical theatre of the University of Salamanca was the first in Spain and perhaps in Europe, since it was ordered to be built in June 1552 and was finished in May 1554, but so far as I know no record exists of what it looked like, though we do know what it was made of and what the materials cost. The one in Padua, in the Palazzo Bo, however, may give us a clue (Figure 1).

It was built in 1594, nearly a hundred years after Alessandro Benedetti published his De Anatomia where he described a theatre that 
could be dismantled and reassembled, ${ }^{8}$ to be used for autopsies, and almost 50 years after Vesalius' De humani corporis fabrica. ${ }^{9}$ It is an elliptical, upside-down cone with six concentric tiers - i.e. seven viewing spaces - with carved wood balustrades. Of the students who came here and returned home with knowledge of the new methods of dissection, two also set up anatomy theatres based directly on the Paduan model, Peter Paaw in the Theatrum Anatomicum in Leiden in 1594 (Figure 2), and Thomas Bartholin (1616 - 1680) in Copenhagen in 1643. Inigo Jones in England also designed an anatomy theatre. ${ }^{10}$

It is interesting that both Padua and Leiden have seven concentric ranks round the little world of man, made cunningly of elements which are being dissected. The spectators become in a (to us) macabre sense analogous to the watching planets circling the world, "judicious sharp spectators" of what is "act[ed] amiss" ${ }^{11}$ There is evidence that the spectators at this hugely popular new activity were surrounded in their ranked places by the skeletal remains of previous dissections: memento mori. (Leiden even looks not unlike our usual mental picture of, well, the Theatre and The Globe.)

What these have in common is the idea of seeing, of something demonstrated, analysed, and inescapably moralized. Even Ortelius' Theatrum is less an atlas in our sense of the word than an analysis of the physical shape of the known world, and the physical world was full of hidden symbolic and moral meaning. Alan of Lille in the twelfth century succinctly summarized an attitude to the world perceived by the senses which Shakespeare and his contemporaries would have recognized. ${ }^{12}$ Bohuslaus Balbinus in Verisimilia humaniorum disciplinarum (Prague, 1666), remarked that there was nothing in the world that was not pregnant with hidden and complex meaning and could not become an emblem.

So, to choose as a name a word that was pretty new in English, so far out of the ordinary it might even needs glossing, and that carried a lot of baggage in Latin, seems to me a major declaration of policy. It is deliberately rather upmarket, and alters the vocabulary. When people talk of what we would call "theatre" in Elizabethan London they use term like "playgoing," "playhouses," "playing," and "Theatre" is not yet connected in common speech with that activity. But "theatre" by 1577 already seems to carry its analytical, even anatomizing, ${ }^{13}$ overtones. Seeing is knowing perhaps. (The word "anatomy" itself was common enough for Shakespeare to use it in Comedy of Errors, and it is used in various but closely related senses in English from 1541.)

The name's strongly moral, intellectual connotations, and its echo of titles in the fashionable emblem genre, suggest the offering of a complex experience, where seeing and hearing are complementary but not necessarily convergent - the whole point of the visual/verbal emblem is that its meaning cannot be contained in either one of its elements, and they may be in tension: both can be true, even if 


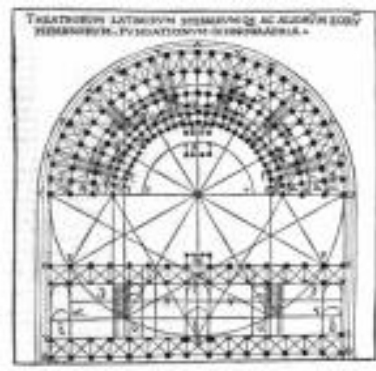

Figure 3 Vitruvius, Ten Books of Architecture V,7: a theatre ground plan.

conflicting. Now, although we rightly remind ourselves that audiences were just that, that they heard plays - in a complex mode of listening we moderns have lost since the brief golden age of what I still call the wireless - and that they were so enjoined to do by for example the Choruses in Henry $V$, they were also spectators, and this word had to be invented (OED's first mention is 1586) to cope with the new concept. It is embraced willingly by Shakespeare. ${ }^{14}$ In a paper to appear soon in Cahiers Elizabethains ${ }^{15}$ I discuss how early modern drama employs the emblematic discourse in exploiting the tension between what is seen, performed by the actors in a special building, and what is heard, where the action becomes like the pictura of an emblem and the dialogue the subscriptio.

The implication of their choice of name is that Burbage and Brayne were claiming the importance and moral seriousness of what they were about to offer. ${ }^{16}$ It might suggest that a seeing place does not have solely an audience, but "judicious sharp spectators," to use Ralegh's phrase, who are themselves actors. It also suggests that, through fabula, it will dissect the affairs of men, revealing their dynamics, their interactions, their significances. The name might even be an attempt to woo a certain clientele, and even perhaps, with its moral overtones, to spike the guns of those hostile to plays.

And when they rebuild across the river, they call it The Globe: Boaistuau's already clichéd conceit, "Theatrum Mundi," makes the name almost inevitable, but it is far from a cliché for a playhouse, and reinforces the claims to moral importance made by the earlier name. "Totus mundus agit histrionem". Whether that was actually the motto of the house has been doubted 17 - it certainly was that of Drury Lane after the redecoration of $1696^{18}$. But let that pass: consider the shape of the building, the "Wooden Nought" - I use E. H. Gombrich's suggested pronunciation. ${ }^{19}$ An unusual name is fitting for a wholly unprecedented building in London of a very odd shape - a shape which must have surprised contemporaries. I know enough from experience of working with precut, ready mortised and drilled green oak to know that in that material it is a pretty major decision to build a polygonal rather than a rectangular structure, and it was perhaps quite a challenge to young Peter Street. Excavation ${ }^{20}$ corroborated the shape of the Globe - and ipso facto The Theatre - in the Hollar Long View, and also supported a remark of Hester Thrale's - whose brewer husband bought the land on which it had stood - about "the curious remains of the old Globe Playhouse, which though hexagonal in form without was round within" (Chambers 2.428). Circular within: in The Theatre of the World (1969), Frances Yates connected this 
shape with Vitruvius' plans for Roman, theatres (Figure 3).

I can think of no major building of that shape before in England. The Theatre/Globe, accommodating between 2500 and 3000 people, was one of the biggest and most visible buildings in London. One might ask, given that texts of Vitruvius were available ${ }^{21}$ - there was a copy in John Dee's library, for example - why, if you are building a theatre, something brand new in England, and you know your classics, as it is a fair guess Burbage did, you do not go straight to the Vitruvian pattern, which saves a lot of design time. Not to do so may have been a choice based as much on what the building was meant to say or signify as on the need to enclose a space so that nobody could melt away from an approaching box, or to remind people of the pageant carts which were in the experience of the actors as well as punters. ${ }^{22}$

Pragmatically, one could argue that the shape, polygonal on the outside and more or less round on the inside, suggests Burbage could have been trying to approach the acoustical ideal recommended by Vitruvius. For every seat was almost equidistant from the stage. Thus - as noted by Vitruvius, who was perfectly aware of the physics of sound - rising and expanding sound waves produced by musical instruments and actors' voices, amplified by the particular shape of the surrounding structure, could be heard equally clearly and distinctly in all sections of the auditorium. Also, the building was wood, which vibrates with sound and resonates so that the whole structure would function like a large musical instrument. But while that is true it is very tempting to suggest that the shape was also importantly symbolic: outside, a polygon's relation to a circle - and the later Rose with its 16 sides takes the idea much further - raises all sort of metaphysical issues, not least the relation between the square and the circle which is expressed by $\Pi .^{23}$ Such mathematical symbolism is commonplace in artistic contexts: Robin Headlam Wells notes how lute roses are also often circles circumscribing polygons and act as reminders of the musica mundi the musica instrumentalis momentarily recaptures. ${ }^{24}$ Among other things, societies use spatial and temporal structures and relationships to comprehend, shape, their world. These can be both physical - measurable, observable - as well as mental, relying on fictional and/or metaphysical assumptions. If Burbage intended to play this metaphorical card, we ought to expect a building that would be a model of the Great Globe itself, and we ought to expect spatial and vertical symmetries and symbols. Which we do seem to get.

In conclusion, two ideas. What would The Theatre, or The Globe, have said to a welltravelled man, who had been to see the sights of Padua or (perhaps easier to get a Privy Council licence?) Leyden, in the 1590s? Second, what was it like to play in The Theatre or The Globe? Which is the actor, which the spectator? The implication of the audience in the transaction with the actors self-declaredly performing a potentially moral fabula forces the question of how plays were watched. The inheritance of 
mediaeval drama, which Helen Cooper and others have demonstrated, can't simply have been shorn of the ritual baggage it carried with it. If we may posit the Elizabethan audience's complicit intimacy with the performance, that takes us straight back to the semiotics of (especially) the mystery dramas, which after all did form the theatrical language of Shakespeare's generation. There the represented action is both distinct, in putative time, from the present actuality and yet is operating in and through it. The audience is no longer simply that, but is involved in the consequences of the action, is challenged by that action, and sees itself and its fate in that action. An audience becomes a crowd on Calvary in an eternal Present. Such drama provided a ritual space where a community could explore its identity. But while the cycle drama in the main took place at an acknowledged season of the ritual year, here that ritual time is replaced by a permanent ritual space, with its own complex symbolism. Hearing/seeing is a willed act, in real time, and it is complementary to acting. Jonson in his preface to the printed text of Hymenaei is admittedly talking about masque, but he does stress the subliminal effects of participation in performance and watching performance - and moral change as a result of it, when minds are "taken with more removed mysteries". 25

\section{Works Cited}

Abbott, Alison. "Hidden treasures: Padua's anatomy theatre." Nature 454, 699 (7 August 2008; Published online 6 August 2008 ).

Abrams, Richard. "Oldys, Motteux and 'the Play'rs old motto:' the 'Totus Mundus' conundrum revisited." Theatre Noteboo k, Vol. 61, No. 3, pp.121-76.

Billing, Christian. "Modelling the anatomy theatre and the indoor hall theatre: Dissection on the stages of early modern London" Early Modern Literary Studies Special Issue 13 (April, 2004).

Limon, Jerzy. "From Liturgy to the Globe: the Changing Concept of Space”. Shakespeare Survey 52: Shakespeare and The Globe. ed. Stanley Wells. Cambridge: Cambridge University Press, 1999.

Nelson, Alan H.. Early Cambridge Theatres: College, University and Town Stages, 1464-1720. Cambridge: Cambridge University Press, 2007.

Orrell, John. The Human Stage: English Theatre Design 1567-1640. Cambridge: Cambridge University Press, 1988.

Potter, Lois. The Life of William Shakespeare: A Critical Biography. Chichester: Wiley Blackwell, 2012.

Stem, Tiffany. "Was Totus Mundus Agit Histrionern Ever the Motto of the Globe Theatre?" Theatre Notebook 51, 1997, 122-27.

Wells, Robin Headlam. Elizabethan Mythologies: Studies in Poetry, Drama and Music. Cambridge: Cambridge University Press, 1994.

West, William N.. "Knowledge and Performance in the Early Modern Theatrum Mundi.” 
http://www.metaphorik.de/sites/www.metaphorik.de/files/journal-pdf/14_2008_west.pdf

(consulted 2 June 2014).

1 Though it might have started a small fashion. In 1599 Philip Henslowe engaged for a playhouse in direct competition to that of the Lord Chamberlain's Men, and it was called the Fortune

2 We know that the other slightly later playhouses had signs. Johannes de Witt noted in 1596 that the two 'more magnificent' of the four theatres he saw 'from the signs suspended before them are called the Rose and the Swan'.

${ }^{3}$ Lois Potter, the Life of William Shakespeare: A CriticalBiography, (Chichester: Wiley Blackwell, 2012) p.53.

4 Vitruvius sees the theatre building as a part of the complex of public buildings needed for a functioning community: 'festival of the gods'.

$\mathbf{5}$ I am indebted to the discussion 'Knowledge and Performance in the Early Modern Theatrum Mundi' by William N. West.

6 (ed.1848, III..187f.).

7 Calvin, Institutes of the Christian Religion, transl. John Allen, 2 vols. (Philadelphia: Philadelphia Board of Christian Education, 2 vols, 1936): see (Calvin's) Book 1, caps. V and VI, and Book 2, cap.6.

${ }^{8}$ Alan H. Nelson, Early Cambridge Theatres: College, University and Town Stages, 1464-1720 (Cambridge: Cambridge University Press, 2007) discusses the temporary theatres that might be erected. The late Professor Iain Wright, who worked on the evidence for the Queens' College theatre, in a private communication to me suggested it could have been used for anatomy demonstrations.

${ }_{9}^{9}$ Alison Abbott, 'Hidden treasures: Padua's anatomy theatre', Nature 454, 699 (7 August 2008; Published online 6 August 2008)

${ }^{10}$ Christian Billing. 'Modelling the anatomy theatre and the indoor hall theatre: Dissection on the stages of early modern London' Early Modern Literary Studies Special Issue 13 (April, 2004): 3.1-17'explores the similarities in design of three 'performance' spaces in early modern London: the indoor hall playhouse, the anatomy theatre, and the cockfighting ring. Inigo Jones designed an anatomy theatre but also built Christopher Beeston's Phoenix playhouse on the foundations of a cockfighting ring to which contemporary regulations prevented substantial alteration. Billing argues that the tragedies of John Ford reflect the performance space anticipated and images of anatomizing are common.

${ }^{11}$ Ralegh's poem 'What is our life?' plays the theatre metaphor for all it is worth

${ }^{12}$ Omnis mundi creatura/ Quasi liber et pictura/Nobis est et speculum;/Nostri mundi, nostrae mortis,/ Nostri status, nostrae sortis, Fidele signaculum. In Migne, Patrologia Latina vol. CCX, col. 579: 'Every created thing in the universe is like a book or a picture, or mirror, to us. It is a faithful sign of our world, our death, our state, our fate.'

${ }^{13}$ E.g. R. Copland, Guy de Chaulac's Questionary Cyrurgyens II,. sig. Biijv, "Anathomy is called ryght dyuysyon of membres done for certayne knowleges". (quoted as OED's example) The word "anatomy" itself was common enough for Shakespeare to use it in Errors, and it is used in various but closely related senses in English from Copland onwards.

14 Shakespeare uses the word six times, the earliest being in $R 2$ and John, where in both case it is self referentially metatheatrical and by which time he is over 30 and with a lot of experience in the theatre behind him.

15 "'Look on this picture, and on this': or 'words,words, words'?"

16 The fact that the majority of 'Jacobethan' plays were comedies does not weaken this point, for comedies could be serious, analytical, moral as well as funny: just in fact as Jonson claimed. (see Helen Cooper, Shakespeare and the Medieval World, London,: Arden Shakespeare, 2010, pp171-3). One might compare the moral importance and subtlety of a lot of medieval romances, the descendants of which formed the popular reading material of the Elizabethans.

17 E.g. by Tiffany Stern, who points out that the evidence or it is rather late. (Tiffany Stem, 'Was Totus Mundus Agit Histrionern Ever the Motto of the Globe Theatre?' Theatre Notebook 51, 1997, 122-27.) T.W. Baldwin established, 'Totus Mundus' derives from a different source (John of Salisbury) than 'All the world's a stage with which it is often linked: the latter comes from Palingenius. ((8) Baldwin, I, 652ff. ). But: Robert Burton says, 'For now as Salisburionsis said in his time, totus mundus histrionem agit, the whole world plaies the foole, we haue a new Theater, a new Sceane, a new comedy of errors, a new company of personat Actors'. This does seem to support Baldwin's view that Burrton is recollecting 'a new comedie of errors ... that the motto was connected with the Globe in [Burton's] mind'. (15) The Comedy of Errors was not a Globe play. But it may have been revived there, and in any case, readers in 1621 would recall the Globe as the quintessential Shakespearian playhouse

18 Richard Abrams, 'Oldys, Motteux and 'the Play'rs old motto': the 'Totus Mundus' conundrum revisited.' Theatre Notebook, Vol. 61, No. 3, pp.121-76.

19 E. H. Gombrich, (\& response by Humphrey Tonkin) Wooden '0' [Shakespeare, Henry V, Prologue, line 13], Times Literary Supplement - Letters, 10 March, 2000 
${ }^{20}$ Current archaeology 225 (December 5, 2008) records the finding of what was thought to be the foundation of The Theatre, which seemed to suggest an octagonal building. The recent discovery of remains of the Curtain suggest it too was probably polygonal: see Cathy Hilts, "Raising the Curtain: Excavating Shakespeare's lost playhouse" Current archaeology ,269 (July 6, 2012).

21 Editions in BL include: Florence 1513, 1522, Venice and Florence 1496, Venice 1511,

Argentorati 1543, 1550, 1586, Rome 1486, 1497np, Lyons 1523, 1552, 1560, Perugia 1536, Rome, 1544.

Crugher Germanum, 1567.

The Strasbourg 1550,copy is annotated by an anonymous early English reader in a fine italic hand with numerous small drawings ( Sold at Sotheby's, London sale, 30 Oct 2007, Lot 3835.)

22 It will be seen that in claiming the building itself permanently conveyed a subtle meaning to the observant playgoer I differ from Jerzy Limon, 'From Liturgy to the Globe: the Changing Concept of Space', Shakespeare Survey 52: Shakespeare and The Globe. ed. Stanley Wells. (Cambridge: Cambridge University Press, 1999.), who argues that the Globe says nothing except that 'I am a place where plays are performed: no symbolism, no nothing'. (p.49)... He argues that it is only through a performance that certain structural elements, through a layer of fictionality, come to mean something.

23 Was the conversion of the frater of Blackfriars, and were the Curtain and the Rose attempts to adapt Roman style for modern audiences? (Orrell, The Human Stage pp.119-29, 115, 157-63)

${ }^{24}$ Elizabethan Mythologies: Studies in Poetry, Drama and Music Cambridge: Cambridge University Press, 1994, pp.113-143

${ }^{25}$ As Ben Jonson put it in the preface to Hymenaei (1606). 